\title{
A novel photonic crystal fibre switch
}

\section{Alkeskjold, Thomas Tanggaard; Hermann, D.S.; Broeng, Jes; Bjarklev, Anders Overgaard}

\section{Published in:}

CLEO/Europe

Link to article, DOI:

10.1109/CLEOE.2003.1313716

Publication date:

2003

Document Version

Publisher's PDF, also known as Version of record

Link back to DTU Orbit

Citation (APA):

Alkeskjold, T. T., Hermann, D. S., Broeng, J., \& Bjarklev, A. O. (2003). A novel photonic crystal fibre switch. In CLEO/Europe (pp. CEP1-9-THU). IEEE. https://doi.org/10.1109/CLEOE.2003.1313716

\section{General rights}

Copyright and moral rights for the publications made accessible in the public portal are retained by the authors and/or other copyright owners and it is a condition of accessing publications that users recognise and abide by the legal requirements associated with these rights.

- Users may download and print one copy of any publication from the public portal for the purpose of private study or research.

- You may not further distribute the material or use it for any profit-making activity or commercial gain

- You may freely distribute the URL identifying the publication in the public portal

If you believe that this document breaches copyright please contact us providing details, and we will remove access to the work immediately and investigate your claim 


\section{A Novel Photonic Crystal Fibre Switch}

Thomas Tanggaard Larsen', David Sparre Hermann², Jes Broeng' ${ }^{3}$ and Anders Bjarklev'

' Research Center COM, Technical University of Denmark, DK-2800 Lyngby, Denmark, Email: ttl@com.diu.dk.

2 Photonics Laboratory, Department of Microtechnology and Nanoscience MC2, Chalmers University of Technology, 41296 Gothenburg, Sweden.

${ }^{3}$ Crystal Fibre A/S, Blokken 84, DK-3460 Birkerød, Denmark

Abstract A new thermo-optic fibre switch is demonstrated, which utilizes the phase transitions of a thermochromic liquid crystal inside a photonic crystal fibre. We report an extinction ratio of $60 \mathrm{~dB}$ and an insertion 1 oss of $1 \mathrm{~dB}$.

Introduction Photonic Crystal Fibres (PCFs) are a new class of optical fibres, which have attracted significant attention during the last few years. PCFs are microstructured fibres, which have a large number of airholes located in the cladding region of the fibre. Within the last couple of years, research activity within this area has expanded to include research on optical functionality incorporated into these fibres[1], and a possible candidate for obtaining tunable PCF devices is Liquid Crystals (LCs).

Experiment In this experiment we used $\approx 60 \mathrm{~cm}$ of a triangular structured all-silica PCF with a hole spacing, hole diameter and core diameter of $7 \mu \mathrm{m}, 3.5 \mu \mathrm{m}$ and $10 \mu \mathrm{m}$, respectively (see inset in figure 2). We filled $10 \mathrm{~mm}$ of the PCF with a chiral short pitch thermochromic LC (TM216 from BDH/Merck), which have the phase transitions: SmA* $26.2^{\circ} \mathrm{C} \mathrm{N}{ }^{*} 42.3^{\circ} \mathrm{C}$ I [2]. The LC was heated to $50^{\circ} \mathrm{C}$ before it was filled into the PCF using the capillary force. The filled fibre was then placed on a small hotplate. At temperatures below $26.2^{\circ} \mathrm{C}\left(\mathrm{T}_{\mathrm{SmA} \mathrm{A}^{*} \mathrm{~N}^{*}}\right)$ the $\mathrm{LC}$ was in its $\mathrm{Smectic} \mathrm{A}^{*}$ phase, where we found the LC to be aligned in an ordered radial symmetry within the PCF holes, by polarized microscopy observations. The director of the LC was perpendicular to the fibre axis, and the smectic layers formed concentric circles within the holes. At temperatures above $T_{\mathrm{Sm}^{*}-\mathrm{N}^{*}}$, the $\mathrm{LC}$ went into its chiral nematic phase (N*), but it was not possible to determine the alignment in the $\mathrm{N}^{*}$ phase. In the SmA* phase, the LC filled holes formed ordered low-scattering rods, which formed a Photonic BandGap structure together with the periodic PCF structure. The transmission spectrum of the filled PCF, below and above $T_{\mathrm{SmA}^{*}-\mathrm{N}^{*}}$, is shown on figure 1 . In the $\mathrm{N}^{*}$ phase, the ordering of the LC changed and the filled holes became highly-scattering rods, which caused the fibre to go into a scattering state with zero transmission. The temperature difference between the transmission state and the scattering state is only $0.4^{\circ} \mathrm{C}$, and by operating the fibre around this $\mathrm{SmA}^{*}$ to $\mathrm{N}^{*}$ phase transition temperature, it was possible to switch between a transmission state and a scattering state. We then prepared a new fibre according to the previously described steps and coated the filled section of the fibre with a conducting epoxy and glued electrodes to each end of the coated section. The resistance of the coated fibre was measured to $\approx 1 \Omega$. By applying a small current through the fibre coating, the filled fibre was heated due to resistive heating. The required voltage to switch between the two states was only $\approx 5 \mathrm{mV}$. To measure the extinction ratio, we coupled a $974 \mathrm{~nm}$ pump laser beam into the filled PCF using butt coupling, and the spectrum in the transmission state and the scattering state was recorded and shown on figure 2 . The extinction ratio was measured to $60 \mathrm{~dB}$ and the overall insertion loss was $1 \mathrm{~dB}$.

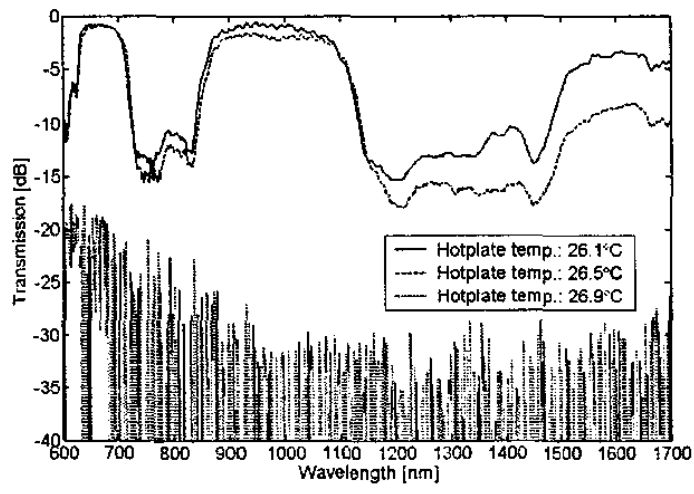

Figure 1 Transmission spectrum of the filled PCF at temperatures below and above $\mathrm{T}_{\mathrm{SmA}^{*}-\mathrm{N}^{*}}$

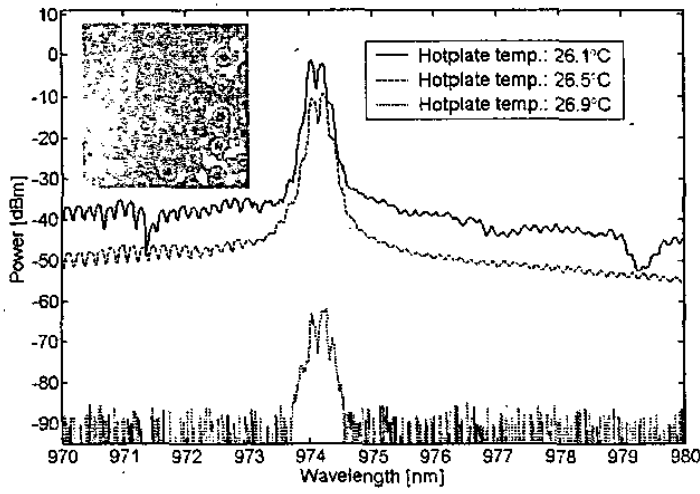

Figure 2 Pump laser spectrum at temperatures below

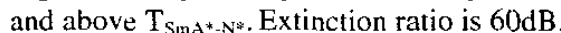

References:

[1] C. Kerbage and B. J. Eggelton, Optics and Photonics News, September 2002, pp. 38-42.

[2] P. Rudquist et al, Journal of applied physics 76 (12), December 1994. 